\title{
AN ESTIMATE OF CHANGE IN A SUB-POPULATION OF LOMATIA TASMANICA (PROTEACEAE) BETWEEN 1993 AND 2008
}

\author{
by Jayne Balmer
}

(with seven text-figures and one table)

\begin{abstract}
Balmer, J. 2009 (11:xii): An estimate of change in a sub-population of Lomatia tasmanica (Proteaceae) between 1993 and 2008. Papers and Proceedings of the Royal Society of Tasmania 143(2): 87-94. https://doi.org/10.26749/rstpp.143.2.87 ISSN 0080-4703. Biodiversity Conservation Branch, Department of Primary Industries, Parks, Water and Environment, GPO Box 44, Hobart, Tasmania 7001, Australia. Email: Jayne.Balmer@dpiwe.tas.gov.au
\end{abstract}

\begin{abstract}
A decline in ramet (plant stem) numbers was observed within a sub-population of Lomatia tasmanica W.M. Curtis between 1993 and 2008. The mortality was mainly among the small ramets. This resulted in a shift from a population dominated in density by recent suckers and young ramets to one dominated by more mature ramets. There was possibly an increased survival rate among ramets cut for genetic sampling in 1993 compared with those that were not pruned. It is suspected that a combination of reduced rainfall and declining light availability has resulted in an increased mortality among young ramets. Although this species is entirely reserved within the Tasmanian Wilderness World Heritage Area it is still vulnerable to random events and climate change and its status as critically endangered remains appropriate. Key Words: threatened plant monitoring, pruning impact, climate change, Southwest National Park, Tasmania, Lomatia tasmanica.
\end{abstract}

\section{INTRODUCTION}

Lomatia tasmanica W.M. Curtis (King's Lomatia) is a member of the plant family Proteaceae Juss. and is listed as critically endangered under the Australian Government's Environmental Protection and Biodiversity Conservation Act 1999. The plant reproduces vegetatively by sending up new plant stems, defined here as ramets, from underground rhizomes (Brown \& Gray 1985). In December 1993 surveys by J. Balmer and others mapped all ramets within one transect region (Lynch \& Balmer 2004) and sampled leaves and population densities from across the known geographic range of the species to determine the genetic variability of the population and estimate the total population of the stand. The genetic study revealed that the population was composed of a single genetic clone (Lynch et al. 1998). Chromosome counts led to the conclusion that the species is a sterile triploid relying entirely on vegetative regeneration for its survival (Lynch et al. 1998, Threatened Species Section 2005). A fossil record of the species from Melaleuca $\left(-43^{\circ} 25^{\prime} \mathrm{S} 146^{\circ} 10^{\prime} \mathrm{E}\right)$ in southwest Tasmania provides evidence that this clonal plant may have been in existence for 43600 years (Jordan et al. 1991, Lynch et al. 1998).

Data from surveys conducted between 1993 and 1996 provided a population estimate for the plant clone of 600 ramets (stems) (Lynch \& Balmer 2004). The total extent of the species is now thought to be about $1.2 \mathrm{~km}$ within the Southwest National Park in Tasmania (Lynch et al. 1998, Threatened Species Unit 2000, Lynch \& Balmer 2004). The habitat for the species ranges from wet scrub to rainforest with most of its extent occurring within riparian areas of mixed forest (Brown \& Gray 1985, Lynch \& Balmer 2004).

The recovery plan for $L$. tasmanica recommends that population monitoring be undertaken "to find more out about this unique species" (Threatened Species Section 2006, p. 15). Monitoring of threatened species is essential to determine if populations are contracting and require management intervention in order to avert further decline and extinction. L. tasmanica has World Heritage significance as an example of the longest-lived plant clone known in the world and has had intense international publicity (Balmer et al. 2004). Despite the success and advantages of asexual reproduction (Cook 1985) L. tasmanica is one of only a few vascular plant taxa that are known to reproduce entirely by asexual means. A few other examples also occur within the family Proteaceae including the endangered clonal shrub Hakea pulvinifera L.A.S. Johnson (Smith 2004). As one of just a few taxa exhibiting this trait, L. tasmanica provides a useful example to test the evolutionary hypothesis that following the extinction of their sexual ancestors, clones will inevitably become extinct without taxonomic descendants (Grant 1981).

This region of southwest Tasmania has experienced a substantial and linear decline in rainfall over the past decade (Bureau of Meteorology data for Maatsuyker Island, Kirkpatrick et al. 2002), with some areas recently receiving less than the $50 \mathrm{~mm}$ summer monthly rainfall considered necessary to maintain rainforest (Jackson 1968). This raises the question of how climate change might impact on plant dynamics within rainforest - especially small relict patches. This further increases the scientific and conservation management interest in monitoring L. tasmanica, one of the few plants to have been intensely surveyed in the region prior to the reduction in annual and summer rainfall.

Another reason for monitoring has been the concern that taking cuttings from L. tasmanica plants may cause shock or allow disease to invade plants, leading to the death of sampled plants in the wild. Potential threats to the species are posed by naturalists and gardeners illegally taking stem samples to propagate the species for horticulture; such visits also increase the potential to introduce disease into the population.

In response to the threatened species recovery plan recommendations and concerns about both the impact of recent rainfall declines and the taking of cuttings from the wild population the area surveyed in 1993 was resurveyed in March 2008. This paper explores the relationships observed between the 1993 and 2008 survey data and tests the following two null hypotheses: (1) the population size and demography of the L. tasmanica stand has not changed between 1993 and 2008; and (2) the health of L. tasmanica ramets from which cuttings were taken is no different from plants from which stem cuttings were not taken. 


\section{METHODS}

\section{3 survey (unpublished DPIW data, Lynch \& Balmer 2004)}

A $75 \mathrm{~m}$ transect line was run out using a tape measure in straight line sections so that it more or less followed the creekline. The changing direction of the transect was recorded in degrees (magnetic) using a Sunto compass and the distance in metres to each bend was noted.

All ramets of $L$. tasmanica observed within $10 \mathrm{~m}$ either side of the transect line (an area of $\sim 1.5$ ha) were recorded together with:

- the distance away from the creek in an approximately eastern (+ve) or western (-ve) direction

- the distance up from the beginning of the transect $(\sim$ northwards)

- an estimate of height or ramet length (to the nearest 500 min)

- the stem diameter in millimetres measured at the base using a diameter tape

- the number of upright ramets arising from a basal rhizome

- notes on the plant health

- a note recording if a cutting was taken

- a ramet identification number.

If a main stem (ramet) was obvious (even when leaning or horizontal) it was recorded and mapped at its point of origin from the ground. However, where a basal horizontal stem was present very close to the ground with more than one main leader arising from it and behaving as individual trees then each of these main leaders was treated as an individual ramet for the purposes of the census.

Flagging tape was tied to each L. tasmanica ramet found to make it clear that they had been recorded. All ramets from which cuttings were taken and an equivalent number of control ramets were tagged with stainless steel measuring labels loosely hung around the branch with the wire enclosed in plastic tubing to protect the plant from abrasion or damage from the tag.

\section{8 census}

In March 2008 all ramets at the site were mapped following the method used in 1993 and an attempt made to match ramets with the original ones located in 1993. The ramets that still bore numbered metal tags or labelled flagging tape were matched precisely with the 1993 survey data. Due to the imprecision of the mapping in 1993 and time constraints for the remapping in 2008 it was not possible to precisely match all ramets between the two sampling periods. Where a plant was located within a metre of a ramet mapped in 1993 this plant was assumed to be the ramet mapped in 1993. Exceptions to this occurred if the ramet in 2008 bore no flagging and was considered too small to have been present in 1993. Three ramets were located in areas where no ramet was mapped in 1993 (including one dead ramet). However, these bore flagging tape suggesting that they had been recorded and had probably been mis-mapped. Final tallies were adjusted to take these probable data collection errors into account.

The software package, MapInfo Professional was used to plot the 1993 transect and 1993 and 2008 ramet distributions (figs 1, 2).

\section{Statistical analysis}

The non-parametric Mann-Whitney (Wilcoxon) W test was used to test if the median stem diameter, stem height or length and distance to the creek were significantly different between the 1993 plants that survived to 2008 compared with those that had died by 2008 . The Chi-squared test was used to test whether mortality was independent of height, stem diameter and the impact of stem cutting.

All living ramets recorded in each of the two time periods within the transect area were used to analyse the significance of population structural differences between the two time periods. The significance of the difference in median values of stem diameter and height of the 2008 and 1993 population was tested using the Mann-Whitney W test. Linear regression and multi-factor analysis of variance was used to test the relative importance of each factor on the survival of plants.

The student t-test was used to compare the difference in the mean climatic data for the 14 years preceding the 1993 and 2008 monitoring visits and the long-term weather data for Maatsuyker Island (the nearest weather station). All tests were performed using the software package, Statgraphics Plus for Windows (Manugistics 2000).

\section{RESULTS}

The total number of living plant stems of L. tasmanica observed in the survey area changed from 103 in 1993 to 84 in 2008 , a decline of $18 \%$. Eight ramets observed in 2008 were small $(<3 \mathrm{~cm}$ diameter or $<600 \mathrm{~mm}$ high) and likely to have regenerated since 1993 ( $10 \%$ of the 2008 population). Fourteen unmarked ramets observed in 2008 could not be matched to the 1993 mapped ramet locations and were estimated to be larger than plants arising since 1993. These unmatched ramets were assumed to have been overlooked in 1993. A total of 41 plants of the 103 live plants recorded in 1993 were either dead or not located and were presumed to have died since 1993 (table 1). Excluding the 2008 unmatched mature plants from the population statistics the decline in plants recorded in 1993 was around 32\% (table 1). If they are added to the original population numbers the decline was $28 \%$.

The survival rate was significantly higher among plants from which cuttings were taken. Only three of the 16 plants sampled from the transect area were found dead in 2008 or not relocated. The Chi-square test with Yates correction factor was only significant at the $90 \%$ level $(\mathrm{p}<0.1)$.

Plants that died prior to March 2008 had significantly smaller diameters and heights in 1993 than those that survived ( $p<0.01$, and $p<0.05$, figs 3,4$)$. The relationship of plant survival and the parameters - stem diameter, height and cutting - was weak and the fitted linear regression models for each of these factors, while all significant $(p<0.05)$, explained only $7 \%, 7 \%$ and $5 \%$ respectively of plant survival. A regression analysis of height and stem diameter showed that they ate significantly correlated $(p<0.0001)$ while the choice of stems cut was not correlated with either stem diameter or height $(p>0.1)$. A multi-factor analysis of variance in survival rate was used to test the relative significance of the contributions of the three factors, height, stem diameter and stems cut. Height and stem cutting each contribute significantly to the variation in survival rate (both 


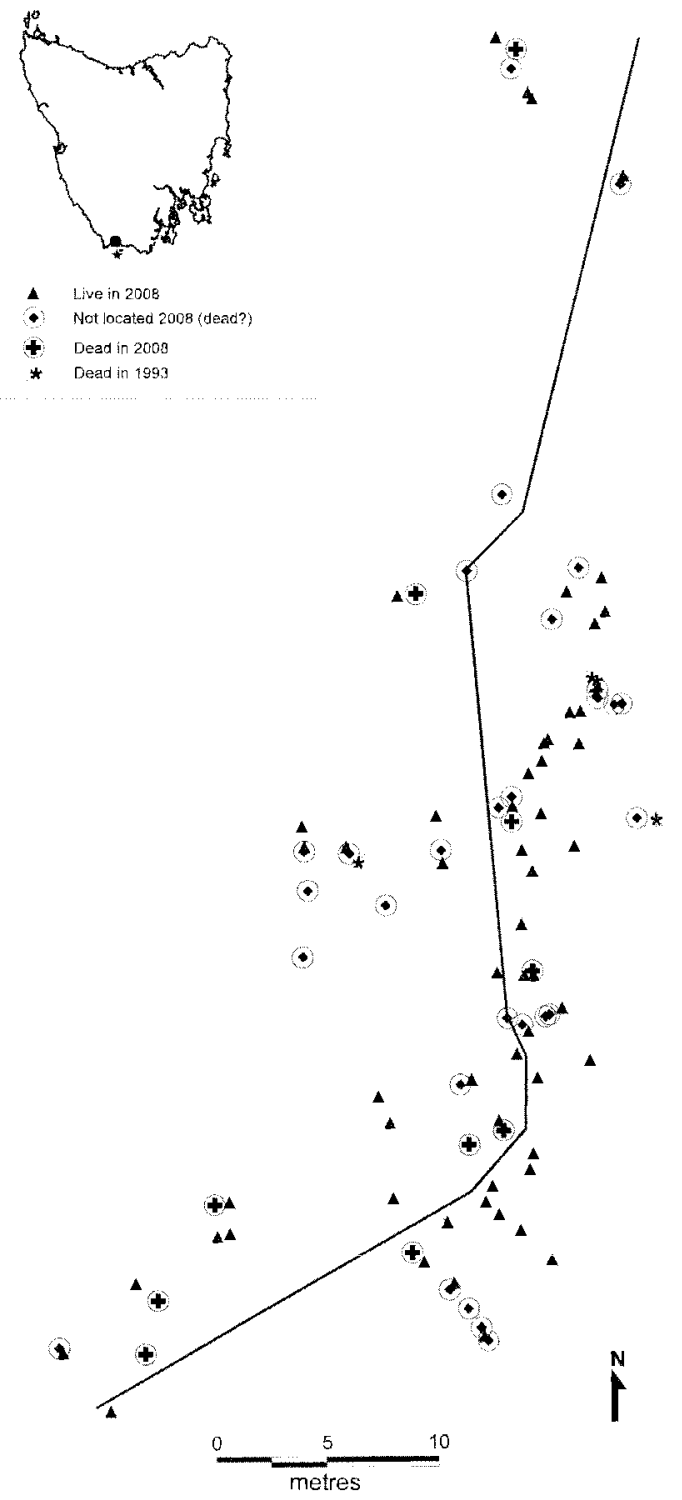

FIG. 1 - Map of ramets in 1993 within $10 \mathrm{~m}$ of the transect-line. The inset map of Tasmania shows the location of the transect (large dot) and the location of the Maatsuyker Island climate station (star).

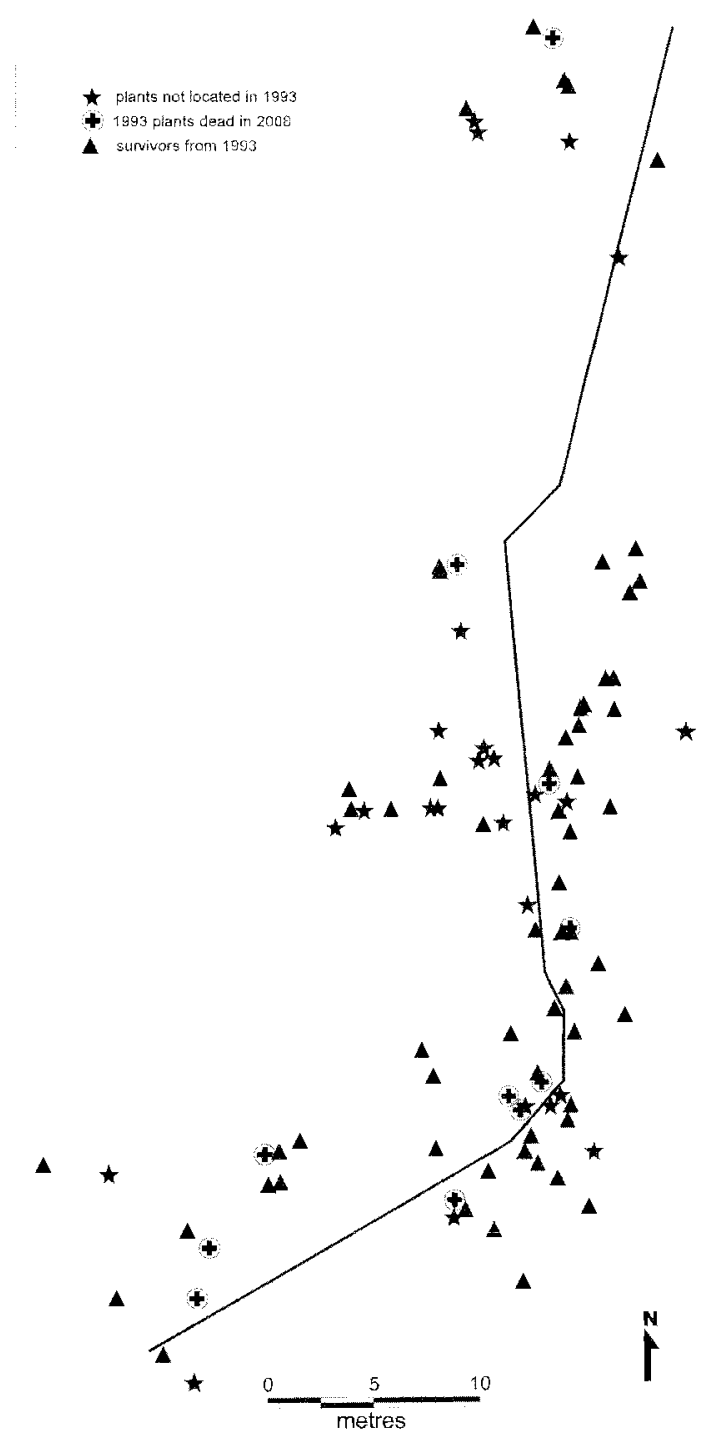

FIG. 2 - Map of ramets in 2008 within $10 \mathrm{~m}$ of the transect-line.

TABLE 1

Tally of plants recorded in 1993 and 2008

\begin{tabular}{|c|c|c|}
\hline Population parameters & Tally of live ramets & Tally of dead ramets \\
\hline Total no. of ramets observed in 1993 [P1] & 103 & 5 \\
\hline Total no. of ramets observed in 2008 & 84 & 11 \\
\hline Live $2008^{\prime}[\mathrm{L}]$ and dead 2008 [DI] & 62 & 11 \\
\hline Unmatched plants regenerated since 1993 [R] & 14 & 0 \\
\hline Unmatched plants (possibly overlooked in 1993) & 8 & 0 \\
\hline Ramets not relocated in 2008 presumed to have died ${ }^{2}$ [D2] & - & 30 \\
\hline Regeneration rate $1993-2008[\mathrm{R} / \text { live live } \mathrm{P} 1]^{3}$ & $8 \%$ & - \\
\hline Mortality rate $1993-2008[\mathrm{D} 1+\mathrm{D} 2 /$ live P1] & - & $40 \%$ \\
\hline Population change $1993-2008[1-\{(\mathrm{L}+\mathrm{R}-\mathrm{D} 1-\mathrm{D} 2) / \text { live } \mathrm{P} 1\}]^{3}$ & - & $-32 \%$ \\
\hline
\end{tabular}

${ }^{1}$ Two live and one dead ramet were marked but did not match locations of any of the plants mapped in 1993.

2 The marked ramets located in areas not matching the original mapped locations were subtracted from the tally of missing plants.

${ }^{3}$ Calculations exclude unmarked mature ramets observed in 2008 not observed in 1993. 
1993 diameter $(\mathrm{mm})$ of plants that died

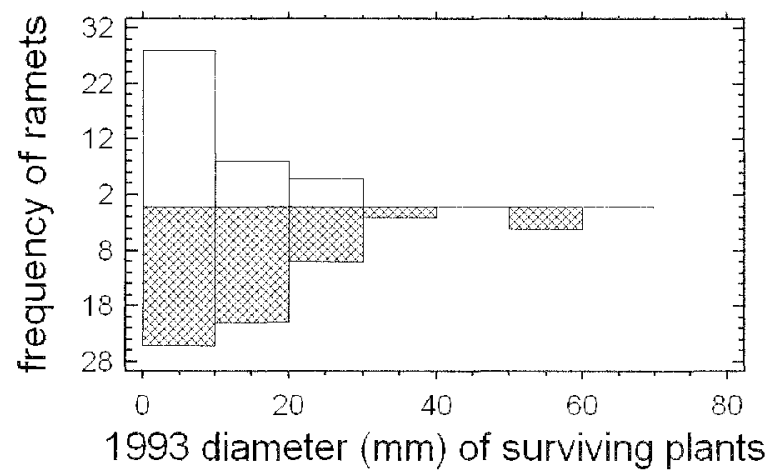

FIG. 3 - Histogram of diameters for the 1993 ramets that survived to 2008 and those that had died by 2008.

2008 diameter $(\mathrm{mm})$

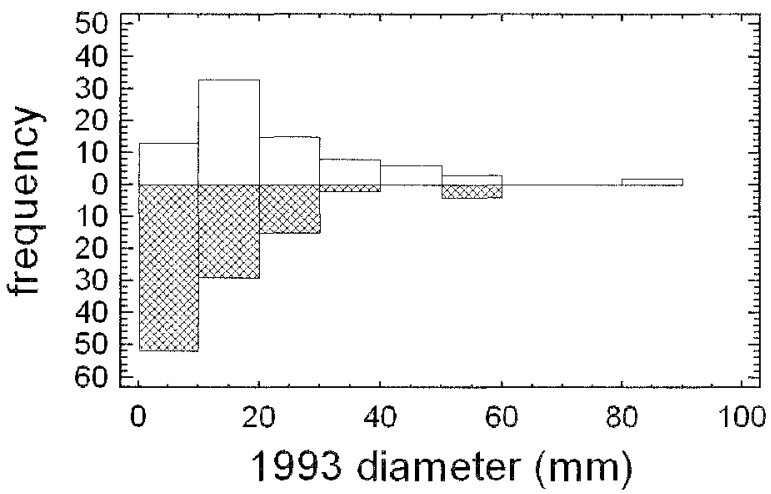

FIG. 5 - Histogram showing changes in population ramet diameters between 1993 and 2008.
Height $(m)$ in 1993 of plants that died

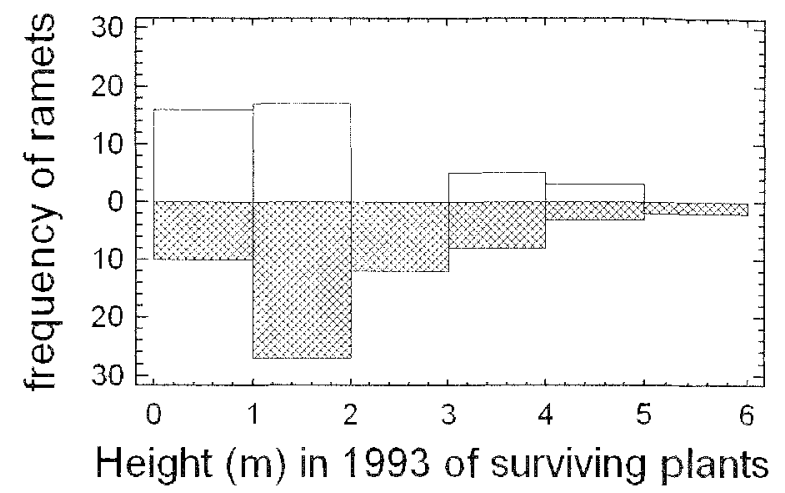

FIG. 4 - Histogram of heights for the 1993 ramets that survived to 2008 and those that had died by 2008.

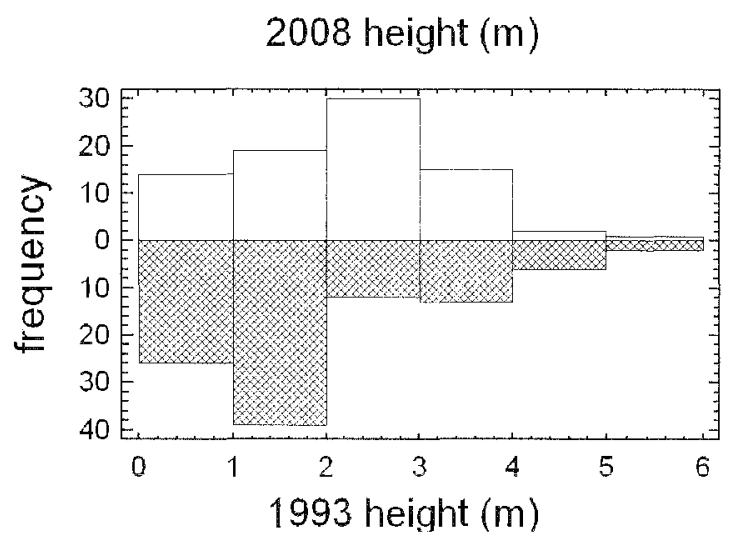

FIG. 6 - Histogram showing changes in population ramet heights between 1993 and 2008.

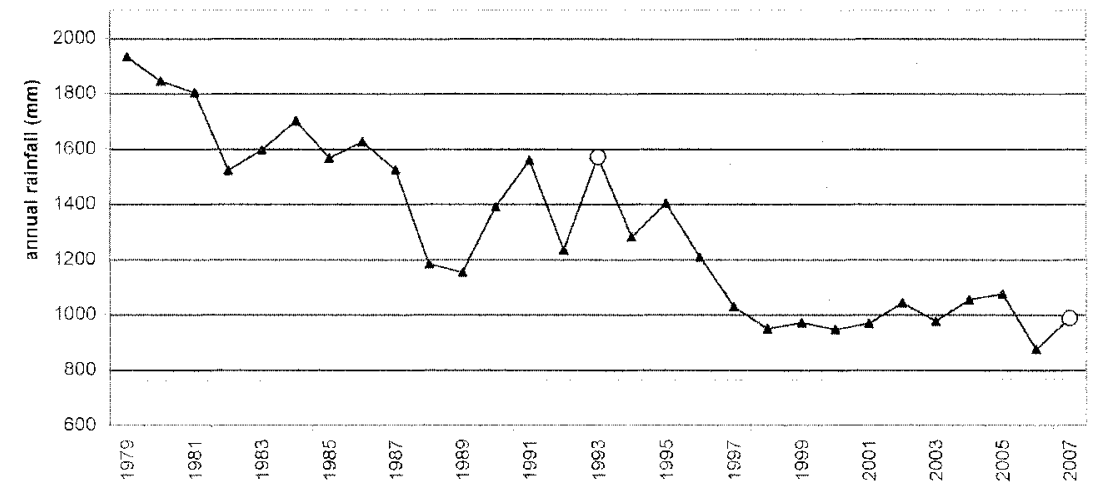

FIG. 7-Annual rainfall at Maatsuyker Island climate station 1979 to 2007. 
$\mathrm{p}<0.05)$ but stem diameter did not provide any additional explanation of the variation $(\mathrm{p}>0.05)$.

The median diametet and height of ramets was significantly different between the two time periods ( $<<0.01$ and $\mathrm{p}<0.0001$ respectively), and the population structure had also changed significantly $(\mathrm{p}<0.05)$ between the two time periods. There were significantly fewer new suckers and young ramets than were recorded in 1993 (fig. 5). Stem diameters and height had increased since 1993 (fig. 6).

There was no statistically significant association berween ramets that died and their proximity to the creek-line $(p>0.1)$.

Weather data from Maatsuyker Island (Bureau of Meteorology data) indicate that the 14 years preceding the 2008 monitoring trip had significantly less annual precipitation than the 14-year period prior to the 1993 monitoring trip ( $\mathrm{p}<0.0001$, fig. 7) as well as being significantly drier than the long-term average $(p<0.02)$. The 14 years preceding 1993 in contrast were significantly wetter than the total 116 years of records $(p<0.001)$. Likewise, the average precipitation for all months was less between 1994 and 2008 compared to the 14-year period up to 1993 . All but February and March had significantly different mean values for monthly precipitation $(\mathrm{p}<0.05)$. Regression analysis showed there was a significant linear decline in rainfall between 1980 and $2008(p<0.0001)$.

With the exception of April there was no significant difference in average annual or monthly maximum or minimum temperatures for the two 14-year periods prior to monitoring ( $p>0.1)$. For April the mean monthly minimum temperatures and mean monthly maximum temperatures for the period 1980 to 1993 were warmer (by less than $\left.1^{\circ} \mathrm{C}\right)$ than both the long-term average $(\mathrm{p}<0.05)$ and for the period 1994 to $2007(p<0.05)$. Temperatures for the 14 -year period prior to the 2008 monitoring survey were not significantly different from the long-term average.

\section{DISCUSSION}

Several problems made the accurate mapping of the $L$. tasmanica ramets challenging. The species is cryptic in the dark rainfotest understorey in which it occurs. In the wild it typically has a slender, spindly, etiolated form, with few lateral branches on which leaves are generally confined to the apex. L. tasmanica regenerates vegetatively by suckering from underground rhizomes and basal stems, creating confusion for the mapping of individuals. Fallen tree limbs and trees within the site surveyed were common and have resulted in the accumulation of dense litter and branch wood on top of the L. tasmanica plants. Due to this and the flexible habit of the species, some of the L. tasmanica plants have fallen over and the lateral branches have become vertical leaders creating further ambiguities for mapping.

\section{Population stability}

Despite the low precision in matching the ramets between the two time periods, it is clear from the data that there has been a real decline of between $18 \%$ and $32 \%$ in ramet numbers in this sub-population of L. tasmanica ovet 14 years (table 1). Therefore the null hypothesis that the population has remained stable between 1993 and 2008 must be rejected.

A similar decline across the range of the stand would have resulted in a drop from the estimated population of about
600 ramets to between 400 and 500 ramets. In addition an ex-situ collection of plants is maintained by the Royal Tasmanian Botanical Gardens (RTBG) with only a very few plants known to occur in private gardens elsewhere (Ken Gillanders pers. comm. 9 April 2009). The RTBG collection declined over the past 12 months because the number of plants that died exceeded the number of new plants propagated taking the total collection from 50 to 44 . Another 52 cuttings are currently in propagation (Lorraine Perrins email, 12 April 2009).

\section{Stand demography}

Population data collected across the range of sites occupied by L. tasmanica between 1993 and 1996 showed the stand structure fitted a reverse J-curve consistent with a continuously regenerating species (Lynch \& Balmer 2004) and consistent with many Tasmanian rainforest tree species (Read \& Hill 1988). The stand demography has altered over the past 14 years at this transect site with the death of a higher proportion of the smaller ramets. The null hypothesis that the demography of the population has not changed between the time periods therefore must be rejected.

\section{Longevity}

The relationship between stem diameter and age has not been determined but Brown \& Gray (1985) recorded 60 rings from a stem $2 \mathrm{~cm}$ in diameter and 240 rings ftom a stem 6 $\mathrm{cm}$ in diameter. On the basis of this limited information, Lynch \& Balmer (2004) hypothesised that most ramets in the population postdated the widespread 1934 wild fire, with very few predating this. The presence of stems of around 8 $\mathrm{cm}$ diameter suggests the species may reach ages of 300 years.

The longevity of plants in horticulture is not known but the high mortality rate suggests that they are shorter lived than those in the wild. The oldest plants in the RTBG collection at present are 11 years old (Lorraine Perrins email, 14 April 2009). An older plant grown from cuttings taken in 1991 died in 2007 at the age of 16 years. L. tasmanica cuttings grafted onto Lomatia tinctoria (Labill.) R.Bt. root stock may potentially have better survival rates with at least one plant propagated in this manner by Gillanders now being 24 years of age (Ken Gillanders pers. comm. 9 April 2009).

\section{Response to having cuttings taken}

The null hypothesis that the taking of stem cuttings does not lead to any changes in plant health compared with those plants which did not have stem cuttings taken requires furthet review, as the data showed a weakly significant association between the taking of cuttings and increased plant survival. It is possible this result may be due to a bias in the sampling towards healthier mature stems over smaller suppressed ramets. Howevet, the lack of correlation between the taking of stem cuttings and ramet size does not support this hypothesis and the possibility that tip pruning enhanced plant vigour cannot be ruled out. Stem cuttings taken from nursery-grown plants rarely results in plant death but neither have they been observed to noticeably improve vigour or lateral branching (Mark Fountain and Natalie Tapson pers. comm. July 2008). The results indicate there is no need to restrict the taking of cuttings providing hygiene and other standard conservation measures to mitigate impacts on plant health are observed. 


\section{Possible explanations for population decline}

Given that the taking of stem cuttings appears unrelated to the observed pattern of mortality, other explanations are required for the population decline observed within the transect area. The following hypotheses are explored here:

- introduction of a plant pathogen such as Phytophthora cinnamomi

- competition for light

- moisture stress

- disturbance from trampling during the 1993 survey.

\section{Pathogen}

Pathogenicity tests have shown that L. tasmanica is susceptible to $P$. cinnamomi (Rudman 2000). This plant pathogen is known to occur within the buttongrass moorland vegetation adjoining the forests in which L. tasmanica occurs but no tests of the soil within the stand or the creek water within the stand have been undertaken to determine if the pathogen has invaded the stand itself (Tim Rudman, Department of Primary Industries, Parks, Water and Environment Files, 8 March 2001).

It is unlikely that the recent decline in ramets could be attributable to this pathogen since studies of the summer soil temperatures in closed forest habitat similar to that along the transect have shown that these soils are too cool to support the growth and reproduction of $P$. cinnamomi (Podger \& Brown 1989, Rudman 2000). Analysis of recent average monthly maximum temperature data for the region showed no significant changes in air temperatures, which is an indication that summer soil temperatures have not increased substantially in recent times although the analysis of averaged monthly data may conceal more subtle changes in climate. Nevertheless, no evidence for $P$. cinnamomi, such as ill health or death of other susceptible species, was observed within the rainforest during the various surveys and visits to the stand.

All visitors to the stand have been asked to follow strict hygiene procedures before entering the forest and visitation is discouraged. This protocol is applied widely in conservation reserves where values are at risk from the spread of this pathogen (Cahill et al. 2008). Here it aims to reduce the chance of introducing long-lived $P$. cinnamomi spores into habitat occupied by L. tasmanica. A disturbance that opens the canopy, such as fire, could enable soil temperatures to increase sufficiently for $P$. cinnamomi to become active leading to the death of susceptible species such as L. tasmanica as they regenerate after the fire (Podger \& Brown 1989, Rudman 2000).

\section{Light availability}

Since the last fire at the site in 1934, the rainforest plants have become increasingly dominant in the understorey and it is likely that this has reduced light penetration to the ground layer. Accumulating litter and branch wood, as well as competition from other ground layer species, may be factors contributing to the higher mortality of small ramets and the reduction in the establishment of new suckers. Data were not collected on relative light availability, plant competition or understorey litter, branch wood or tree falls so that this hypothesis was unable to be tested. Nevertheless, the greater importance of height for survival and the relative lack of importance of stem diameter in the multi-factor analysis of variance suggests that it was the plants with the greatest leaf area or leaves higher above the ground that were more likely to survive. These plants are likely to intercept a greater amount of light.

The vigour of plants in the wild is poor compared to plants grown in gardens and nurseries where light is more freely available and competition is reduced suggesting that light may be a limiting factor in the wild. Nevertheless the species is very sun-sensitive and requires shade (Mark Fountain and Natalie Tapson pers. comm. July 2008). A study of ramet response to light variation in a species of bamboo showed that low light conditions inhibited the production of ramets, and resulted in ramets with longer internode lengths but no mortality was recorded (Yue et al. 2004).

\section{Moisture stress}

The average rainfall for the region in the 14-year period up to 2008 was c. $1000 \mathrm{~mm}$ per year, much lower than the preceding 14-year period when it fluctuated between 1200 and $1800 \mathrm{~mm}$ (fig. 7). This has shifted the rainfall closer to the lower limit for the maintenance of rainforest vegetation of about $1000 \mathrm{~mm}$ average annual per year and $50 \mathrm{~mm}$ average summer monthly rainfall (Jackson 1968). The higher than average rainfall experienced in the years leading up to 1993 may have given rise to an increased production of ramets that have subsequently died. Kirkpatrick et al. (2002) suggested that a decline in graminoid and herb cover in the alpine vegetation on the Southern Ranges between 1990 and 2000 may have been related to the significant linear decline in rainfall between 1980 and 2000 . No other study in southwest Tasmania has looked at vegetation responses to recent climatic changes.

Reduced moisture availability is known to reduce the production of proteoid roots in some members of the Proteaceae (Lamont 1986). In general, plants with proteoid roots are able to extract phosphorous from nutrient-deficient soils more effectively than other plants, even those with mychorrhizal associations (Pearson \& Rengel 1997). If L. tasmanica has such roots it is possible that if moisture levels are reduced then the plant's ability to absorb phosphorous will decline, reducing its competitive ability in this lownutrient environment.

\section{Spatial distribution of plant death}

The spatial pattern of the dead plants relative to the living population was not statistically tested for its deviation from random. The disturbance from survey work is likely to have been relatively evenly distributed across the population or concentrated in the region of the creek-line where the transect-line was located. However, the deaths appear to be loosely clustered in parches rather than being evenly dispersed or concentrated along the creek-line, so there is no apparent relationship between the site survey conducted in 1993 and the pattern of deaths observed.

Plants with proteoid roots, such as those in the genus Lomatia and many other members of the Proteaceae (Purnell 1960), may be particularly sensitive to root disturbance (Lamont 1986). Certainly the disturbance of potting up plants and moving them is strongly associated with an increased mortality (Lorraine Perrins pers. comm. July 2008 and April 2009). A recent death of the most mature pot plant in the RTBG collection followed the removal of liverworts from the soil surface. Tests did not reveal the cause 
of the death but the symptoms of sudden blackening of all the leaves suggested that the plant may have been shocked by the light root disturbance causing the release of toxic phenolic compounds which led to its death.

Given the apparent sensitivity of this species to root disturbance some impact from trampling during the survey of 1993 cannot be dismissed.

\section{Clonal plant responses to resource limitations}

Each ramet of L. tasmanica is part of a larger colonial plant. The duration of the connections between $L$. tasmanica ramets is not known but studies of Populus showed that root connections between clonal trees may persist for up to 50 years while others decay quickly (Pitelka \& Ashmun 1985). Clonal plants can, and regularly do, share resources (Cook 1985, Pitelka \& Ashmun 1985). They are also able to "forage" by altering their growth in response to resource availability, but despite this their success may be dependent on the spatial arrangement of suitable habitat (Cain et al. 1996). Observations and ecological theory about dynamics of clonal populations suggest that the parent plants typically expend energy to support their daughters and that this leads to a higher rate of establishment by clones compared with seedlings (Thomas \& Dale 1975, Cook 1985). Populations are fairly stable over long periods of time with increases in appearance of new plants tending to be associated with increased rates of mortality which are typically seasonal (Noble et al. 1979, Fletcher \& Shaver 1983, Cook 1985). More recent theoretical models suggest that habitat patchiness and variability is likely to determine whether the strategy of maintaining integration between clonal plants is more advantageous to the genet than the strategy of splitting clonal progeny from parent plants (Kun \& Oborny 2003, Mágori et al. 2003). Since the degree to which $L$. tasmanica splits or remains integrated is unknown, the implications of this on its capacity to respond successfully to changes in habitat remain unclear.

\section{CONCLUSIONS}

The results of this study show the importance to conservation management of longitudinal studies to monitor changes in the population of threatened species and the risks of placing too much reliance on the results of single surveys. They also highlight that threatened species are vulnerable both within and outside the reserve system. Species restricted to the reserve system may be vulnerable to benign neglect by land managers struggling to find sufficient funds to manage the growing reserve system.

It is probable that the decline in numbers of ramets observed in the transect area is part of a natural response to climatic variation and/or light availability. A study of the size class structure of L. tasmanica across its range is needed to determine if the decline observed in this sub-population is part of a more widespread trend.

While there has been a decline in younger plants, the survival of the mature plants suggests that the sub-population is not under immediate risk of local extinction. Regeneration is still occurring albeit at a lower rate than previous observations suggested. If declining rainfall is responsible for the population change then further drying may well have serious implications for the regeneration dynamics and survival of L. tasmanica in the region. Its presence within a national park in the Tasmanian Wilderness World Heritage Area does not offer any protection against this threat. Other species with limited dispersal capacity and sensitivity to drought are also likely to be at risk from declines in local regional rainfall. While climate modelling for the Tasmanian and Australian region has not yet predicted any significant changes in the climate of southwest Tasmania it is based on very limited data and hence has a low reliability for this region (McIntosh et al. 2005, CSIRO \& the Australian Bureau of Meteorology 2007).

Given the threats to the wild population of L. tasmanica, the maintenance of an ex-situ population of the species is important (Threatened Species Section 2006). Although a clone, the low rate of survival of plants in horticulture suggests that the ex-situ collection should be no less than 50 plants. The establishment of longer lived material by grafting onto hardy root stock would also be a sensible precaution. The development of a cheap, mass propagation technique for the species would enhance the long-term survival chances of the species by:

- increasing the total number of extant plants in horticulture

- reducing the need to visit the wild population in order to see the species

- reducing the illegal taking of cuttings from the wild

- enabling the efficient propagation of the species for replanting in the event of a wildfire or any other catastrophic event destroying the wild population.

A first attempt to develop a tissue culturing technique for the species was begun at the University of Tasmania in 1994 (Cambecèdes 1995). This research is continuing as a collaborative project between the University of Tasmanian and the RTBG (Anthony Katoulis and Lorraine Perrins pers. comm. April 2009) and the project's continuation is recommended.

Further ecological studies of $L$. tasmanica are also desirable if there is to be any chance of understanding and conserving this unique species in the wild. Priority research questions include:

- Does L. tasmanica have proteoid roots and what ramifications does this have for horticulture?

- How sensitive to trampling impacts is the plant and what measures can be taken to minimise impacts of visitation to the wild population?

- How long do ramets maintain connections with each other? This has ramifications on stand maintenance through resource sharing and partitioning.

- Is light or other competition a limiting factor for regeneration of the species in the wild and if so could it be alleviated by active canopy thinning or removing of competing species, dead branchwood and other litter?

- What prompts the formation of new ramets, and what is their growth rate?

- Are current summer soil temperatures sufficiently low to protect the species from being impacted by Phytophthora cinnamomi should it invade?

- Are spores of P. cinnamomi already in the soil within the L. tasmanica stand?

\section{ACKNOWLEDGEMENTS}

Jasmyn Lynch and Karen Johnson took part in the field survey work in 1993 and 2008 respectively. Colin Reid provided GIS assistance with the original mapping of the 1993 data. This project was funded by the Australian Government through 
the Tasmanian Wilderness World Heritage Area program. The climatic data were supplied by the Australian Bureau of Meteorology. Valuable comments on the draft manuscript were provided by Jennie Whinam, Jasmyn Lynch and Stephen Harris. Staff from the Royal Tasmanian Botanical Gardens provided information about the survival of plants within their collection.

\section{REFERENCES}

Balmer, J., Whinam, J., Kirkpatrick, J.B. \& Lazarus, E. 2004: A review of the floristic values of the Tasmanian Wilderness World Heritage Area. Nature Conservation Report 2004/3, Department of Primary Industries, Water and Environment, Hobart: $129 \mathrm{pp}$.

Brown, M.J. \& Gray, A. 1985: Lomatia tasmanica: a rare endemic plant from South West Tasmania. Tasmanian Naturalist 83: 1-5.

Cahill, D.M., Rookes, R.E., Wilson, B.A., Gibson, L. \& McDougall, K.L. 2008: Turner Review No, 17. Phytophthora cinnamomi and Australia's biodiversity: impacts, predicrions and progress towards control. Australian Journal of Botany 56: 279-310.

Cain, M.L., Dudle, D.A. \& Evans, P.A. 1996: Spatial models of foraging in clonal plant species. Australian Journal of Botany 83:76-85.

Cambecèdes, J. 1995: Final report on the Australian Flora Foundation funded project: Lomatia tasmanica and Persoonia muelleri propagation and commercial horticulture. Unpublished report to the Australian Flora Foundation Parks and Wildlife Service, Department of Environment and Land Management, Hobart: 11 pp.

Cook, R.E. 1985: Growth and development in clonal plant populations. In Jackson, J.B.C., Buss, L.W. \& Cook, R.E. (eds): Populations Biology and Evolution of Clonal Organisms, Yale University Press, New Haven: 259-296.

CSIRO \& the Australian Bureau of Meteorology 2007: Climate change in Australia: Technical report 2007. CSIRO Marine and Atmospheric Research, Aspendale: 148 pp.

Fletcher, N. \& Shaver, G.R. 1983: Life histories of tillers of Eriophorum vaginatum in relation to tundra disturbance. Journal of Ecology 71: 131-147.

Grant, V. 1981: Plant speciation. 2nd edn., Columbia University Press, New York: 435 pp.

Jackson, W.D. 1968: Fire, air, water, earth - an elemental ecology of Tasmania. Proceedings of the Ecological Society of Australia 3: 9-16.

Jordan, G.J., Carpenter, R.J. \& Hill, R.S. 1991: Late Pleistocene vegetation and climate near Melaleuca Inlet, South-western Tasmania. Australian Journal of Botany 39: 315-333.

Kirkpatrick, J.B., Bridle, K.L. \& Lynch, A.J.J. 2002: Changes in alpine vegetation related to geomorphological processes and climatic change on Hill One, Southern Range, Tasmania, 1989-2000. Australian Journal of Botany 50:753-759.

Kun, Á. \& Oborny, B. 2003: Survival and competition of clonal plant populations in spatially and temporally heterogeneous habitats. Community Ecology 4: 1-20.

Lamont, B.B. 1986: The significance of Proteoid toots in Proteas. Acta Horticulturae 185: 163-170.

Lynch, A.J.J. \& Balmer, J. 2004: The ecology, phytosociology and stand structure of an ancient endemic plant Lomatia tasmanica (Proteaceae) approaching extinction. Australian Journal of Botany 52: 619-627.

Lynch, A.J.J., Barnes, R.W., Cambecèdes, J. \& Vaillencourt, R.E. 1998: Genetic evidence that Lomatia tasmanica is an ancient clone. Australian Journal of Botany 46: 25-33. McIntosh, P., Pook, M. \& McGregor, J. 2005: Study of future and current climate: A scenario for the Tasmanian region, Stages 2 and 3, A report for Hydro Tasmania by CSIRO Marine and Atmospheric Research. CSIRO, Hobart: $68 \mathrm{pp}$.

Mágori, K., Oborny, B., Dieckmann, U. \& Meszéna, G. 2003: Cooperation and competition in heterogeneous environments: the evolution of resource sharing in clonal plants. Evolutionary Ecology Research 5: 1-31.

Manugistics 2000: STATGRAPHICS Plus Version 5 Online Manual. Manugistics Inc, Rockville: 733 pp. www. statgraphics.com

Noble, J.C., Bell, A.D. \& Harper, J.L. 1979: The structural demography of rhizomatous plants: Carex arenaria L. 1. The morphology and flux of modular growth units. Journal of Ecology 67: 983-1008.

Pearson, J.N. \& Rengel, Z. 1997: Mechanisms of plant resistance to nutrient deficiency stress. Chapter 10. In Basra, A.S. \& Basra, R.K. (eds): Mechanisms of Environmental Stress Resistance in Plants. Harwood Academic Publishers, Amsterdam: 213-240.

Pitelka, L.F. \& Ashmun, J.W. 1985: Physiology and integration of ramets in clonal plants. In Jackson, J.B.C., Buss, L.W. \& Cook, R.E. (eds): Populations biology and evolution of clonal organisms, Yale University Press, New Haven: 399-435.

Podger, F.D. \& Brown, M.J. 1989: Vegetation damage caused by Phytophthora cinnamomi on disturbed sites in temperate rainforest in western Tasmania. Australian Journal of Botany 37: 493-480.

Purnell, H.M. 1960: Studies of the family Proteaceae. I. Anatomy and morphology of the roots of some Victorian species. Australian Journal of Botany 8: 38-50.

Read, J. \& Hill, R.S. 1988: The dynamics of some rainforest associations in Tasmania. Journal of Ecology 76: 558-584.

Rudman, T. 2000: Susceptibility of Lomatia tasmanica to Phytophthora cinnamomi and implications for management. Unpublished internal report of the Department of Primary Industries, Water \& Environment, Hobart: 4 pp.

Smith, J. 2004: Invesrigating sterility in the clonal shrub Hakea pulvinifera: comparative studies of reproductive biology, floral development and genetic variation. A report for the Australian Flora Foundation. Unpublished report, School of Rural Science and Agriculture, University of New England, http://www.aff.org.au/Taji_Hakea_final_2004. pdf (last accessed 9 April 2009).

Thomas, A.G. \& Dale, H.M. 1975: The role of seed reproduction in the dynamics of established populations of Hieracium floribundum and a comparison with that of vegetative reproduction. Canadian Journal of Botany 53: 3022-3031.

Threatened Species Unit 2000: Draft 03/10/00 Threatened Species Listing Statement King's Lomatia, Lomatia tasmanica W.M. Curtis, 1967. Department of Primary Industries, Water \& Environment, Hobart: 4 pp.

Threatened Species Section 2005: Lomatia tasmanica Note Sheet, www.dpiw.tas.gov.au/inter.nsf/Attachments/SSKA756W2H/\$FILE/Lomatia\%20tasmanica.pdf (last accessed 9 April 2009).

Threatened Species Section 2006: Flora Recovery Plan: King's lomatia, Lomatia tasmanica 2006-2010. Department of Primary Industries, Water \& Environment, Hobart: 22 pp. www.dpiw.tas.gov.au/inter.nsf/Attachments/LJEM6VM7DH?open (last accessed 9 April 2009).

Yue, C., Change, J., Wang, K. \& Zhu, W. 2004: Response of clonal growth in Phyllostachys praecox $\mathrm{f}$. prevernalis to changing light intensity. Australian Journal of Botany 52: 171-174.

(accepted 9 July 2009) 